ISSN: 2146-3042

DOI: $10.25095 /$ mufad.756151

\title{
Muş Alparslan Üniversitesi Öğrencilerinin Genel Muhasebe Algılarına Yönelik Metaforlar*
}

\author{
Cuma FIDAN* \\ İsmail AĞIRBAŞ**
}

\section{$\ddot{O Z Z E T}$}

Araştırmanın amacı, genel muhasebe dersini alan ögrencilerin muhasebe kavramına yönelik algılarını "renk, hayvan, besin, mevsim, oyun, çiçek ve eşya" metafor kavramları aracıliğıyla incelemektir. Çalışma, nitel araştırma yöntemlerinden olgubilim çalışma deseni kapsamında gerçekleştirilmiştir. Araştırmada veri toplama aracı olarak yarı yapılandırılmış mülakat yöntemi kullanılmıştır. Araştırmaya, 2018-2019 bahar döneminde Muş Alparslan Üniversitesi'nde genel muhasebe dersini alan toplam 269 ögrenci katılmıştır. Formlardan elde edilen veriler, betimsel analiz ile analiz edilmiştir. Çalışmada uzman görüşü alınarak araştırmanın inanırlığ arttırlmıştır. Araştırmada yaş, cinsiyet, bölüm/program, ders durumu; renk, hayvan, besin, mevsim, oyun ve eşya metafor kavramları ve muhasebe algılarına yönelik bulgular elde edilmiştir. Araştırmada elde edilen bulgular doğrultusunda olumsuz muhasebe algisının giderilmesine, ders müfredatının hazırlanmasına ve geliştirilmesine yönelik bir çözüm önerisi sunulmuştur.

Anahtar Kelimeler: Genel Muhasebe, Metafor, Muhasebe Algisı.

JEL Sinıflandirması: M40, M41.

\section{Metaphors Related to Muş Alparslan University Students' Perceptions of General Accounting \\ ABSTRACT}

The aim of the research is to examine the perceptions of the students who take general accounting course about the concept of accounting through metaphor concepts such as "color, animal, food, season, game, flower and object". The study was carried out within the scope of the phenomenology study design which is one of the qualitative research methods. In the research, semi-structured interview method was used as the data collection tool. A total of 269 students who took general accounting course at Muş Alparslan University in 2018-2019 spring semester participated in the study. The data obtained from the forms were analyzed by descriptive analysis. The credibility of the research was increased by taking expert opinion in the study. Findings related to the students' metaphor concepts of age, gender, department / program, course status,color, animal, food, season, game, object and their perceptions of accounting were obtained. In line with these findings of the research, a solution proposal for the elimination of negative accounting perception and preparation and development of the course curriculum was presented.

Keywords: General Accounting, Metaphor, Accounting Perception. Jel Classification: M40, M41.

\footnotetext{
* Makale Gönderim Tarihi: 17.09.2019, Makale Kabul Tarihi: 07.11.2019, Makale Türü: Nicel Araştırma

* Arş. Gör., Muş Alparslan Üniversitesi Sağlık Yüksekokulu Sağlık Yönetimi Bölümü; Doktora Öğrencisi, Ankara Üniversitesi Sağlık Bilimleri Enstitüsü, cmfdn91 @ gmail.com, ORCID ID: 0000-0002-8581-5940.

** Prof. Dr., Ankara Üniversitesi Sağlık Bilimleri Fakültesi Sağlık Yönetimi Bölümü, agirbasismail@yahoo.com, ORCID ID: 0000-0002-1664-5159.
} 


\section{GíRiş}

Öğrencilerin işletme amaçlarına uyum sağlamasında ve bu amaçları gerçekleştirebilmesinde muhasebe eğitimi önemli bir rol oynamaktadır. Muhasebe eğitiminde konuların zor olması (Martinis ve Tidd, 2011: 432), dersle ilgili ön yargılar (Franco ve Roach, 2017: 22; Jones ve Fields, 2001: 531), öğrenme (Chen vd., 2013: 2815) ve matematiksel işlem kaygısı (Warwick ve Howard, 2016: 1) gibi faktörler öğrencilerin muhasebe algılarında farklılıklara neden olmaktadır. $\mathrm{Bu}$ algıların belirlenmesinde metafor çalışmaları kullanılabilmektedir (Akpınar ve Yıldız, 2018: 92). Somut kavramlar ve imgeler yoluyla soyut kavramların anlaşılmasını (Ke vd., 2019: 1; Kalaycı, 2018: 4) ve bireylerin algılarını anlamayı sağlayan metaforlar (Abay vd., 2017: 3; Çalışkan, 2013: 9); müfredat geliştirme ve planlamada, öğrenmeyi teşvik etme ve yaratıcı düşünceyi geliştirmede ve öğretim uygulamalarını yönlendirmede kullanılır (İbret vd., 2018: 424; Jensen, 2006: 39).

Literatürde yapılan metafor çalışmalarının çoğunlukla eğitim bilimleri alanında yapıldığı ve ayrıca çalışmaların sağlı bilimleri ve yönetim ve organizasyon bilimleri alanlarında da yapıldığı görülmüştür (Beyoğlu ve Ergin, 2019; Büyükalan ve Yaylacı, 2018; Nas ve Sak, 2018; İbret vd., 2018; Kalayc1, 2018; Köroğlu vd., 2018; Okur Özdemir ve Arık, 2018; Uğurlu, 2018; Sağlam Kaya, 2017; Süer vd., 2017; Taşdemir ve Taşdemir, 2016; Uygun vd., 2016; Aydın ve Sulak, 2015; Pesen vd., 2015; Zembat vd., 2015; Karaçam ve Aydın, 2014; Altun ve Camadan, 2013; Karakuş, 2013; Kaya, 2013; Saban, 2009; Uyar Suiçmez, 2019; Öztaş vd., 2018; Abay vd., 2017; Kale ve Çiçek, 2015; Üzüm ve Uçkun, 2019; Çelik ve Sağlam Arı, 2017; Fidan, 2017; Onay ve Ergüden, 2012; Doğan ve Üngören, 2010).

Muhasebe dersini alan öğrencilerin muhasebe algılarını belirlemeye yönelik alanyazında yapılan araştırmaların çoğunlukla anket çalı̧̧maları (Karavadar ve Paça, 2019; Kutlu vd., 2017; Kandemir vd., 2016; Warwick ve Howard; 2016; Demirel Utku ve Erol, 2015; Duman vd., 2015; Dizman, 2015; Erol ve Demirel Utku, 2015; Özbek, 2015; Varıcı ve Bulut, 2015; Yıldırım, 2015; Atmaca ve Çoşgun, 2014; Ertuğrul ve Özdemir, 2014; Aygün ve Gerekan, 2012; Çelenk vd., 2010; Cheng, 2007) olduğu görülmüştür. Bu çalışmalardaki anket soruları, muhasebe dersi ile ilgili olarak "başarı durumu, kaygı, özgüven, belirsizlik, ön yargı, istek, zekâ, dersi alma sebepleri, öneriler vb." kavramlarına yönelik sorulardır. Literatürde muhasebe algıların belirlemeye yönelik yapılan metafor çalışmalarında (Erol Fidan, 2019; Akpınar ve Yıldız, 2018; Güler vd., 2016) ise mülakat soruları metafor kavramlarına yönelik sorulardır. Dolayısıyla literatürde muhasebe algılarını belirlemeye yönelik yapılan metafor çalışmalarının diğer alanlarda yapılan çalışmalara oranla az sayıda yapıldığ görülmüş̧ür. $\mathrm{Bu}$ nedenle çalışmada, Muş Alparslan Üniversitesi'nde genel muhasebe dersini alan ön lisans ve lisans öğrencilerin muhasebe dersine yönelik algılarının metafor kavramları aracıllğ̆ıla ortaya konması amaçlanmıştır. Ayrıca genel muhasebe dersine yönelik olumsuz algının giderilmesine ve ders müfredatının geliştirilmesine ve planlanmasına bir çözüm önerisi sunması bakımından çalışmanın literatüre katkı sağlayacağı düşünülmektedir. 


\section{GENEL MUHASEBE DERSİ ALGILARINA YÖNELIK METAFOR ÇALIŞMASI}

Çalışma, nitel araştırma desenlerinden olgubilim deseni çerçevesinde gerçekleştirilmiştir. Olgubilim deseni, farkında olunan ve ayrıntılı bir anlayışa sahip olunmayan olgularda kullanılmaktadır (Yıldırım ve Şimşek, 2013: 78). Dolayısıyla çalışmanın amacı, genel muhasebe dersini alan ön lisans ve lisans öğrencilerinin muhasebe kavramına ilişkin algılarını ortaya koymaktır. Araştırmanın amacından hareketle çalışmanın temel problemi "Genel muhasebe dersini alan öğrencilerin muhasebe algıları nasıl şekillenmektedir?" olarak belirlenmiştir. Araştırmanın temel problemine bağlı olarak aşağıdaki araştırma sorularına yanıt aranmıştır:

1. Genel muhasebe dersini alan öğrencilerin yaş grupları nedir?

2. Genel muhasebe dersini alan öğrencilerin cinsiyeti nedir?

3. Genel muhasebe dersini alan öğrencilerin kayıtlı olduğu bölüm/program nedir?

4. Genel muhasebe dersini alan öğrencilerin ders durumu nedir?

5. Genel muhasebe dersini alan öğrencilerin renk metaforları nelerden oluşmaktadır?

6. Genel muhasebe dersini alan öğrencilerin hayvan metaforları nelerden oluşmaktadır?

7. Genel muhasebe dersini alan öğrencilerin besin metaforları nelerden oluşmaktadır?

8. Genel muhasebe dersini alan öğrencilerin mevsim metaforları nelerden oluşmaktadır?

9. Genel muhasebe dersini alan öğrencilerin oyun metaforları nelerden oluşmaktadır?

10. Genel muhasebe dersini alan öğrencilerin çiçek metaforları nelerden oluşmaktadır?

11. Genel muhasebe dersini alan öğrencilerin eşya metaforları nelerden oluşmaktadır?

\subsection{Veri Toplama Süreci}

Araştırmada veri toplama aracı olarak yarı yapılandırılmış mülakat formu kullanılmıştır. Formda yaş, cinsiyet, bölüm/program, ders durumu sorularının yanı sıra öğrencilerin muhasebe kavramına ilişkin algılarını ortaya koymaları amacıyla öğrencilerden "Muhasebe bir (renk, hayvan, besin türü, mevsim, oyun, çiçek ve eşya) olsaydı ... olurdu. Çünkü ...”"cümlelerini tamamlamaları istenmiştir. Öğrencilerin formu doldurmalarında yüz yüze iletişim yöntemi kullanılmıştır. Bu süreçte öğrencilerin seçtikleri metafor kavramları ile muhasebe algıları arasında muhasebe dersi ile bir ilişkinin kurulmuş olmasına özellikle dikkat edilmiş̧tir. Muhasebe dersi ile iliş̧kilendirilmeyen formlar tespit edildiğinde formun öğrenciler tarafından yeniden cevaplandırılması istenmiştir. Muş Alparslan Üniversitesi 2018-2019 bahar döneminde genel muhasebe dersini alan 428 aktif öğrenci vardır. Araştırmaya muhasebe dersini alan 269 öğrenci çalışmaya katılmayı kabul etmiştir. Araştırmada genel muhasebe dersini alan tüm öğrencilere ulaşılması hedeflenmiştir. Ayrıca araştırmanın uygulanabilmesi için Muş Alparslan Üniversitesi Rektörlüğü’nden ve Bilimsel Araştırma ve Yayın Etiği Kurulu’ndan gerekli izin ve onaylar alınmıştır. 


\subsection{Veri Analiz Süreci}

Araştırmaya katılan öğrencilerin formlarından elde edilen bilgiler Microsoft Office Excel programına aktarılmıştır. Veriler betimsel analiz yöntemi ile analiz edilmiştir. Betimsel analizde veriler, daha önceden belirlenen temalara göre analiz edilir (Yıldırım ve Şimşek, 2013: 256). Araştırma verilerinin kodlanmasında literatürde yapılan çalışmalar (Erol Fidan, 2019; Akpınar ve Yıldız, 2018) temel alınmıştır. Araştırmada ilk olarak öğrencilerin yaş, cinsiyet, bölüm/program ve ders durumu ile ilgili verileri analiz edilmiştir. Daha sonrasında öğrencilerin metafor kavramlarına (renk, hayvan, besin türü, mevsim, oyun, çiçek ve eşya) verdikleri cevaplar analize tabi tutulmuştur. Veri analiz sürecinde son olarak, öğrencilerin metafor kavramlarını kullanarak muhasebe dersine yönelik algıları analiz edilmiştir. Öğrencilerin bu algıları, "Muhasebe bir ... olsaydı ... olurdu. Çünkü ..." sorusundaki "Çünkü” ile verdikleri cevaplardan oluşmaktadır. Bu cevaplar dikkate alınarak muhasebe algıları (Zor, sıkıcı, karmaşı; gerekli, faydalı ve önemli; dikkat ve çok çalışma gerektiren; kurallı, düzenli ve sistematik; heyecan verici; zekâ gerektiren; diğer bilim dallarıyla ilişkili; parayla ilişkili; yol gösterici bir ders olarak muhasebe) metafor kavramlarına verilen cevaplar dikkate alınarak belirlenmiştir.

\subsection{Araştırmanın İnanırlığı}

Araştırmacının yanlılığını azaltmak, temaları doğru belirlemek, verileri doğru analiz etmek ve araştırmanın inanırlığını arttırmak için uzman incelemesi yöntemi kullanılır (Başkale, 2016: 24). Nitel araştırma yöntemleri konusunda uzman kişiden (Dr. Öğr. Üyesi, eğitim bilimleri alanında uzman) araştırmayı incelemesi istenerek araştırmanın inanırlığ arttırılmıştır. Çalışmada uzman incelemesi sonucu aşağıdaki değişiklikler yapılmıştır:

- "Genel muhasebe dersini alan öğrencilerin muhasebe algıları nasıl şekillenmektedir?” araştırma sorusu çalışmanın temel problemi olarak belirlenmiştir. Araştırmanın temel problemine göre araştırma soruları yeniden ele alınmıştır.

- Genel muhasebe dersini alan ön lisans ve lisans öğrencilerinin algısal farklılıkları, öğrenci sayılarındaki eşitsizlik nedeniyle, bölümlere/programlara göre incelenmemiştir.

- Araştırmada sunulan tabloların oluşturulmasında ve anlaşılmasında belirli frekansın altında kalan alt temalara "Diğer" kategorisi altında yer verilmiştir.

- Metafor kavramları ile ilgili bulgulara öğrencilerin muhasebe dersi ile ilgili düşüncelerinin bir kaçına yer verilmiştir.

\subsection{Araştırmanın Sınırlılıkları}

Araştırma, genel muhasebe dersini alan Muş Alparslan Üniversitesi'ndeki ön lisans ve lisans bölümlerindeki/programlarındaki öğrenciler ile sınırlandırılmıştır. Ayrıca araştırmada metafor kavramlarına bağlı alt temalara herhangi bir sınıflandırma yapılmadan yer verilmiştir. 


\section{BULGULAR}

Genel muhasebe dersini alan öğrencilerin yaş grupları Tablo 1'de gösterilmiştir.

Tablo 1. Öğrencilerin Yaş Grupları

\begin{tabular}{|c|c|c|}
\hline Yaş & $\mathbf{N}$ & $\%$ \\
\hline $18-21$ & 145 & 53,90 \\
\hline $22-25$ & 117 & 43,49 \\
\hline 26- & 7 & 2,60 \\
\hline Toplam & 269 & 100,00 \\
\hline
\end{tabular}

Tablo 1'de görüldüğg̈ gibi, öğrencilerin yaş dağılımı 18-21, 22-25 ve 26 yaş ve üstü olarak sınıflandırılmış ve genel muhasebe dersini alan öğrenciler çoğunlukla 18-21 yaş $(\mathrm{N}=145, \%=53,90)$ arasindadır.

Genel muhasebe dersini alan öğrencilerin cinsiyeti Tablo 2'de gösterilmiştir.

Tablo 2. Öğrencilerin Cinsiyeti

\begin{tabular}{|c|c|c|}
\hline Cinsiyet & $\mathbf{N}$ & $\%$ \\
\hline $\mathrm{E}$ & 142 & 52,79 \\
\hline $\mathrm{K}$ & 127 & 47,21 \\
\hline Toplam & 269 & 100,00 \\
\hline
\end{tabular}

Tablo 2'de görüldüğü gibi, genel muhasebe dersini alan öğrencilerin 142'si erkek ve 127 'si ise kadın öğrencidir.

Genel muhasebe dersini alan öğrencilerin kayıtlı olduğu bölüm/program Tablo 3'te gösterilmiştir.

Tablo 3. Öğrencilerin Kayıtlı Olduğu Bölüm/Program

\begin{tabular}{|l|c|c|}
\hline \multicolumn{1}{|c|}{ Bölüm } & N & \% \\
\hline Sağlık Kurumları İşletmeciliği Programı & 62 & 23,05 \\
\hline Finans Bankacılık ve Sigortacılık Programı & 39 & 14,50 \\
\hline Raylı Sistemler İşletmeciliği Programı & 38 & 14,13 \\
\hline İktisat Bölümü & 35 & 13,01 \\
\hline Yerel Yönetimler Programı & 29 & 10,78 \\
\hline İşletme Bölümü & 28 & 10,41 \\
\hline Büro Yönetimi ve Yönetici Asistanlı̆̆ı Programı & 23 & 8,55 \\
\hline Muhasebe ve Vergi Uygulamaları Programı & 8 & 2,97 \\
\hline İşletme Yönetimi Programı & 4 & 1,49 \\
\hline Turizm ve Otel İşletmeciliği Programı & 3 & 1,12 \\
\hline \multicolumn{1}{|c|}{ Toplam } & $\mathbf{2 6 9}$ & $\mathbf{1 0 0 , 0 0}$ \\
\hline
\end{tabular}


Tablo 3'te görüldüğü gibi, genel muhasebe dersini alan öğrenciler 2 farklı bölüm ve 8 farklı program olmak üzere toplamda 10 bölüm/programda kayıtlı olduğu ve öğrencilerin çoğunlukla Sağlık Kurumları İşletmeciliği $(\mathrm{N}=62, \%=23,05)$, Finans, Bankacılık ve Sigortacılık $(\mathrm{N}=39, \%=14,50)$ ve Raylı Sistemler İşletmeciliği $\quad(\mathrm{N}=38, \%=14,13)$ programlarında öğrenim gördüğü görülmektedir.

Genel muhasebe dersini alan öğrencilerin ders durumu Tablo 4’te gösterilmiştir.

Tablo 4. Öğrencilerin Ders Durumu

\begin{tabular}{|c|c|c|}
\hline Ders Durumu & $\mathbf{N}$ & $\%$ \\
\hline Geçti & 158 & 58,74 \\
\hline Alttan & 81 & 30,11 \\
\hline İlk kez & 30 & 11,15 \\
\hline Toplam & 269 & 100,00 \\
\hline
\end{tabular}

Tablo 4'te görüldüğü gibi, genel muhasebe dersini alan öğrencilerin ders durumu geçti, alttan ve ilk kez kategorilerinde ele alınmıştır. Dersi alan öğrencilerin 158'i dersi geçerken, 81'i ise dersi alttan almaktadır. Genel muhasebe dersini ilk kez alan öğrenciler $(\mathrm{N}=30, \%=11,15)$ ise bölüm/programların birinci sınıf öğrencileridir. Genel muhasebe dersini alan öğrencilerin renk metaforları Tablo 5'te gösterilmiştir.

Tablo 5. Öğrencilerin Renk Metaforları

\begin{tabular}{|l|c|c|}
\hline \multicolumn{1}{|c|}{ Renk } & N & \% \\
\hline Siyah & 134 & 49,81 \\
\hline Kırmızı & 29 & 10,78 \\
\hline Mavi & 26 & 9,67 \\
\hline Gri & 22 & 8,18 \\
\hline Beyaz & 20 & 7,43 \\
\hline Yeșil & 9 & 3,35 \\
\hline $\begin{array}{l}\text { Diğer (Sarı (n=5), Pembe (n=5), Mor (n=4), Turuncu (n=4), Lacivert (n=4), Kahverengi (n=3), } \\
\text { Lila (n=2), Bordo (n=1), Eflatun (n=1)) }\end{array}$ & 29 & 10,78 \\
\hline \multicolumn{1}{|c|}{ Toplam } & $\mathbf{2 6 9}$ & $\mathbf{1 0 0 , 0 0}$ \\
\hline
\end{tabular}

Tablo 5'te görüldüğü gibi, genel muhasebe dersini alan öğrencilerin renk metaforları çoğunlukla siyah $(\mathrm{N}=134, \%=49,81)$, kırmızı $(\mathrm{N}=29, \%=10,78)$ ve mavi $(\mathrm{N}=26, \%=9,67)$ renkleridir. Öğrencilerin renk metaforunu kullanarak muhasebe dersine ilişkin görüşlerinin "Siyah renk ile işletmelerin tüm işlemlerinde kullanılması gerektiği, en küçük hataya dahi yer verilmediği, anlaşılması zor ve iç karartıcı olduğu; kırmızı renk ile bir düzeni ifade ettiği, çarpıcı, dikkat çekici ve riskli olduğu ve mavi renk ile de güveni temsil ettiği, sonsuz, detaylı ve karmaşık olduğu" şeklinde olduğu görülmüştür. 
Genel muhasebe dersini alan öğrencilerin hayvan metaforları Tablo 6'da gösterilmiştir.

Tablo 6. Öğrencilerin Hayvan Metaforları

\begin{tabular}{|c|c|c|}
\hline Hayvan & $\mathbf{N}$ & $\%$ \\
\hline Yilan & 31 & 11,52 \\
\hline Kedi & 26 & 9,67 \\
\hline Aslan & 23 & 8,55 \\
\hline Köpek & 16 & 5,95 \\
\hline Tilki & 14 & 5,20 \\
\hline Eşek & 8 & 2,97 \\
\hline İnek & 8 & 2,97 \\
\hline Kuş & 8 & 2,97 \\
\hline Timsah & 8 & 2,97 \\
\hline 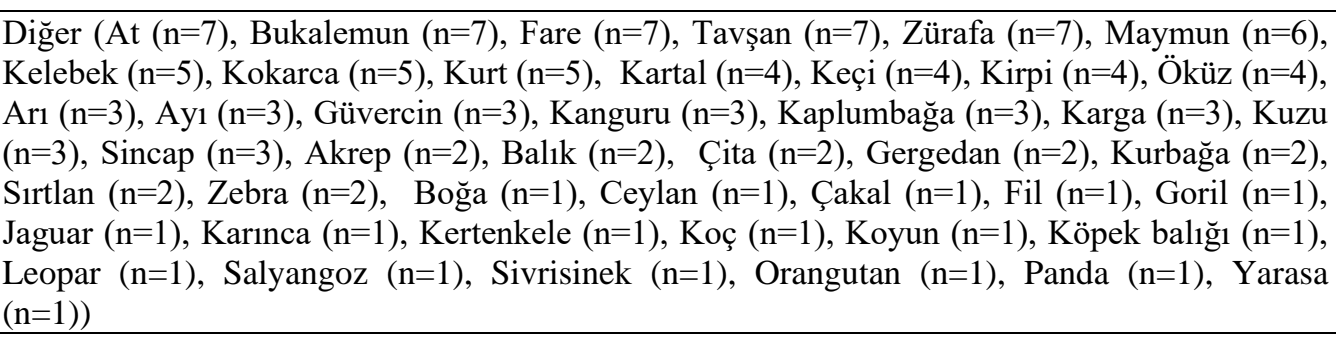 & 127 & 47,21 \\
\hline Toplam & 269 & 100,00 \\
\hline
\end{tabular}

Tablo 6'da görüldüğü gibi, genel muhasebe dersini alan öğrencilerin hayvan metaforları çoğunlukla yılan $(\mathrm{N}=31, \%=11,52)$, kedi $(\mathrm{N}=26, \%=9,67)$ ve aslan $(\mathrm{N}=23$, $\%=8,55)$ hayvan türleridir. Öğrencilerin hayvan metaforunu kullanarak muhasebe dersine yönelik bakış açılarının arasında "Yılan metaforu ile korkutucu ve tehlikeli olduğu; kedi metaforu ile emek verilmesi gerektiği, nankör olduğu ve yanlışların telafisinin olmadığı ve aslan metaforu ile de işletmeyi güçlü kıldığ şeklinde olduğu görülmüştür.

Genel muhasebe dersini alan öğrencilerin besin metaforları Tablo 7'de gösterilmiştir.

Tablo 7'de görüldüğ̈̈ gibi, genel muhasebe dersini alan öğrencilerin besin metaforları arasında acı biber $(\mathrm{N}=27, \%=10,04)$, et $(\mathrm{N}=15, \%=5,58)$ ve soğan $(\mathrm{N}=14, \%=5,20)$ besin türleri ön plana çıkmaktadır. Öğrencilerin besin metaforunu kullanarak muhasebe dersi ile ilgili düşüncelerinin "Acı biber metaforu ile vazgeçilmez olduğu ve acı verdiği; et metaforu ile olmazsa olmaz olduğu ve maliyetinin fazla olduğu ve soğan metaforu ile de emek verilmesi gerektiği, gerekli olduğu ve acı verdiğii” şeklinde olduğu görülmüştür. 
Tablo 7. Öğrencilerin Besin Metaforları

\begin{tabular}{|c|c|c|}
\hline Besin & $\mathbf{N}$ & $\%$ \\
\hline Ac1 Biber & 27 & 10,04 \\
\hline $\mathrm{Et}$ & 15 & 5,58 \\
\hline Soğan & 14 & 5,20 \\
\hline Brokoli & 13 & 4,83 \\
\hline Lahana & 7 & 2,60 \\
\hline Pirasa & 7 & 2,60 \\
\hline 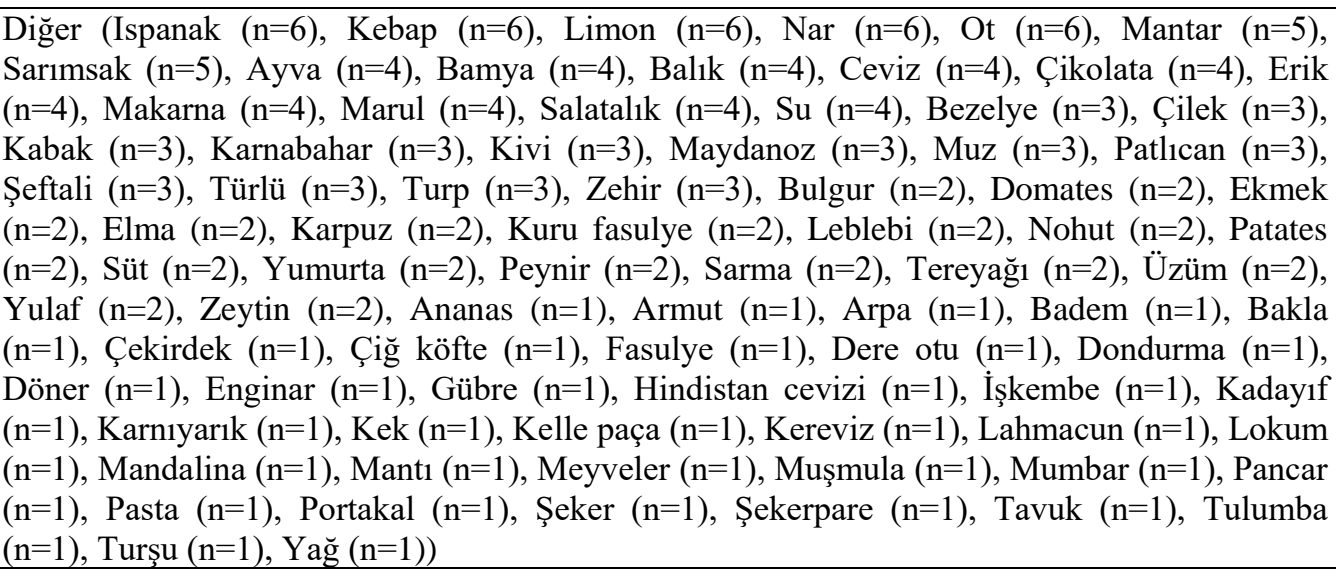 & 186 & 69,14 \\
\hline Toplam & 269 & 100,00 \\
\hline
\end{tabular}

Genel muhasebe dersini alan öğrencilerin mevsim metaforları Tablo 8'de gösterilmiştir.

Tablo 8. Öğrencilerin Mevsim Metaforları

\begin{tabular}{|c|c|c|}
\hline Mevsim & $\mathbf{N}$ & $\%$ \\
\hline Kış & 149 & 55,39 \\
\hline Sonbahar & 60 & 22,30 \\
\hline İlkbahar & 48 & 17,84 \\
\hline Yaz & 12 & 4,46 \\
\hline Toplam & 269 & 100,00 \\
\hline
\end{tabular}

Tablo 8'de görüldüğü gibi, genel muhasebe dersini alan öğrencilerin mevsim metaforları çoğunlukla kış $(\mathrm{N}=149, \%=55,39)$ ve sonbahar $(\mathrm{N}=60, \%=22,30)$ mevsim türleridir. Öğrencilerin mevsim metaforunu kullanarak muhasebe dersine yönelik düşüncelerinin "kış mevsimi ile yeni bir dönemin başladığını, zor ve çetin olduğu ve sonbahar mevsimi ile de belirli bir kurala sahip olduğu, yanlışın telafi edilemeyeceği, iç karartıcı ve zor olduğu" şeklinde olduğu görülmüştür. 
Genel muhasebe dersini alan öğrencilerin oyun metaforları Tablo 9'da gösterilmiştir.

Tablo 9. Öğrencilerin Oyun Metaforları

\begin{tabular}{|c|c|c|}
\hline Oyun & $\mathbf{N}$ & $\%$ \\
\hline Saklambaç & 48 & 17,84 \\
\hline Bilgisayar oyunu & 43 & 15,99 \\
\hline Körebe & 29 & 10,78 \\
\hline Satranç & 26 & 9,67 \\
\hline Yakalamaca & 15 & 5,58 \\
\hline Futbol & 14 & 5,20 \\
\hline Okey & 14 & 5,20 \\
\hline Su doku & 11 & 4,09 \\
\hline Zekâ oyunu & 11 & 4,09 \\
\hline $\begin{array}{l}\text { Diğer }(\text { Yapboz }(n=7) \text {, Seksek }(n=6) \text {, Halay }(n=5) \text {, Basketbol }(n=4) \text {, Batak }(n=4) \text {, Yakan top } \\
(n=3) \text {, Bilardo }(n=2) \text {, Bulmaca }(n=2) \text {, Ip atlama }(n=2) \text {, Puzzle }(n=2) \text {, Tabu }(n=2) \text {, Voleybol } \\
(n=2) \text { Yedi kule }(n=2) \text {, Beştaş }(n=1) \text {, Boks }(n=1) \text { Bowling }(n=1) \text {, Dama }(n=1) \text {, El } \\
\text { kızartmaca }(n=1) \text {, Golf }(n=1) \text {, Hentbol }(n=1) \text {, Karate }(n=1) \text {, Monopoli }(n=1) \text {, Lego }(n=1) \text {, } \\
\text { Pis yedili }(n=1) \text {, Poker }(n=1) \text {, Simit }(n=1) \text {, Tavla }(n=1) \text {, Tenis }(n=1))\end{array}$ & 58 & 21,56 \\
\hline Toplam & 269 & 100,00 \\
\hline
\end{tabular}

Tablo 9'da görüldüğü gibi, genel muhasebe dersini alan öğrencilerin oyun metaforları arasında saklambaç $(\mathrm{N}=48, \%=17,84)$, bilgisayar oyunu $(\mathrm{N}=43, \%=15,99)$ ve körebe $(\mathrm{N}=29$, $\%=10,78$ ) oyun türleri ön plana çıkmaktadır. Öğrencilerin oyun metaforunu kullanarak muhasebe dersi ile ilgili bakış açısının "Saklambaç oyunu ile net, kurallı, zor ve anlaşılmaz olmasi; bilgisayar oyunu ile eğlenceli, kurallı olması ve zaman alması ve körebe oyunu ile de bilinmezliğin çok olması" şeklinde olduğu görülmüştür.

Genel muhasebe dersini alan öğrencilerin çiçek metaforları Tablo 10'da gösterilmiştir.

Tablo 10. Öğrencilerin Çiçek Metaforları

\begin{tabular}{|c|c|c|}
\hline Çiçek Türü & $\mathbf{N}$ & $\%$ \\
\hline Kaktüs & 114 & 42,38 \\
\hline Papatya & 61 & 22,68 \\
\hline Gül & 39 & 14,50 \\
\hline Lale & 13 & 4,83 \\
\hline Sarmaşık & 9 & 3,35 \\
\hline $\begin{array}{l}\text { Diğer (Kardelen }(n=7) \text {, Isırgan otu }(n=5) \text {, Karanfil }(n=5) \text {, Orkide }(n=5) \text {, Menekşe }(n=4) \text {, Ay } \\
\text { ciçeği }(n=1) \text {, Et yiyen }(n=1) \text {, Fesleğen }(n=1) \text {, Gelincik çiçeği }(n=1) \text {, Kır çiçeği }(n=1) \text {, } \\
\text { Krizantem }(n=1) \text {, Rehan }(n=1))\end{array}$ & 33 & 12,27 \\
\hline Toplam & 269 & 100,00 \\
\hline
\end{tabular}

Tablo 10'da görüldüğü gibi, genel muhasebe dersini alan öğrencilerin çiçek metaforları çoğunlukla kaktüs $(\mathrm{N}=114, \%=42,38)$, papatya $(\mathrm{N}=61, \%=22,68)$ ve gül $(\mathrm{N}=39$, $\%=14,50$ ) çiçek türleridir. Öğrencilerin çiçek metaforunu kullanarak muhasebe dersine 
yönelik düşüncelerinin "Kaktüs ile zorlukların üstesinden gelinen, faydalı, gerekli, zahmetli ve dikkat gerektiren olması; papatya ile çok yönlü ve karmaşık olması ve gül ile de emek, dikkat ve ilgi istiyor olması" ş̧eklinde olduğu görülmüştür.

Genel muhasebe dersini alan öğrencilerin eşya metaforları Tablo 11'de gösterilmiştir.

Tablo 11. Öğrencilerin Eşya Metaforları

\begin{tabular}{|c|c|c|}
\hline Eşya & $\mathbf{N}$ & $\%$ \\
\hline Hesap Makinesi & 26 & 9,67 \\
\hline Dolap & 21 & 7,81 \\
\hline Kalem & 19 & 7,06 \\
\hline Masa & 10 & 3,72 \\
\hline Ayna & 9 & 3,35 \\
\hline Biçak & 9 & 3,35 \\
\hline Buzdolab1 & 9 & 3,35 \\
\hline Telefon & 9 & 3,35 \\
\hline Bilgisayar & 8 & 2,97 \\
\hline 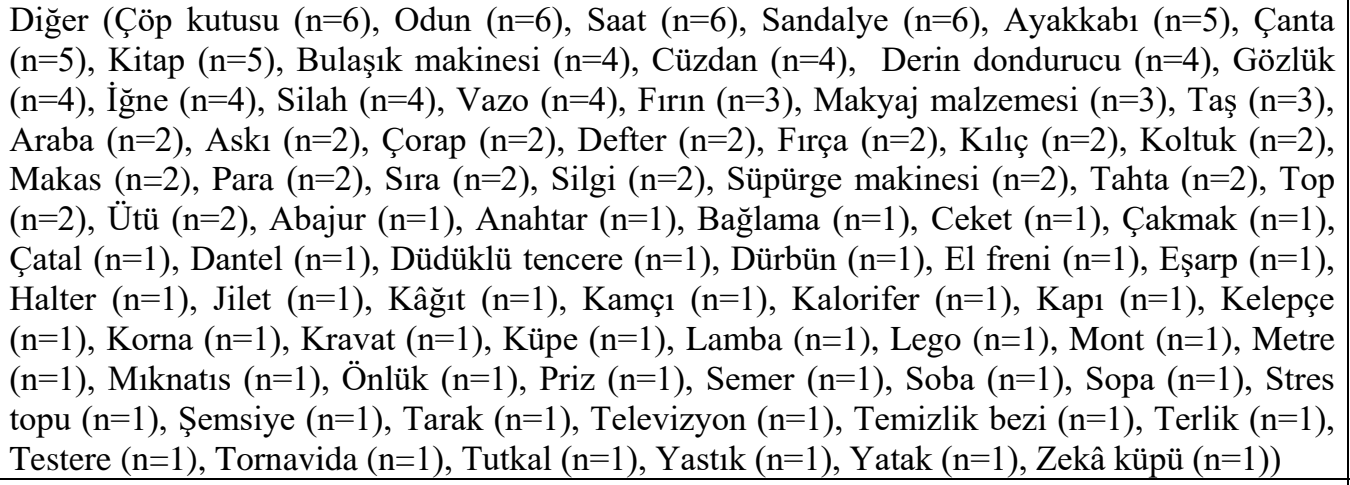 & 149 & 55,39 \\
\hline Toplam & 269 & 100,00 \\
\hline
\end{tabular}

Tablo 11'de görüldüğü gibi, genel muhasebe dersini alan öğrencilerin eşya metaforları arasinda hesap makinesi $(\mathrm{N}=26, \%=9,67)$, dolap $(\mathrm{N}=21, \%=7,81)$ ve kalem $(\mathrm{N}=19, \%=7,06)$ eşya türleri ön plana çıkmaktadır. Öğrencilerin eşya metaforunu kullanarak muhasebe dersine yönelik bakış açılarının "Hesap makinesi ile gerekli, kurallı, dikkat gerektiren ve karmaşık olması; dolap ile düzenli, sistematik ve zor olması ve kalem ile de gerekli, önemli ve faydalı olması" şeklinde olduğu görülmüştür.

Genel muhasebe dersini alan öğrencilerin muhasebe algıları Tablo 12'de gösterilmiştir. 
Tablo 12. Öğrencilerin Muhasebe Algiları

\begin{tabular}{|c|c|c|c|c|c|c|c|c|c|}
\hline Muhasebe Algıları & $\stackrel{\varkappa}{\ddot{E}}$ & 馬 & 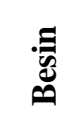 & 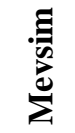 & $\Xi$ & 菤 & 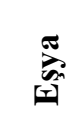 & 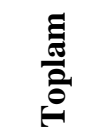 & $0^{\circ}$ \\
\hline $\begin{array}{l}\text { Zor, sıkıcı ve karmaşık bir ders olarak } \\
\text { muhasebe }\end{array}$ & 141 & 138 & 146 & 168 & 129 & 141 & 112 & 975 & 51,78 \\
\hline $\begin{array}{l}\text { Gerekli, faydalı ve önemli bir ders olarak } \\
\text { muhasebe }\end{array}$ & 31 & 39 & 59 & 37 & 36 & 54 & 88 & 344 & 18,27 \\
\hline Heyecan verici bir ders olarak muhasebe & 55 & 22 & 26 & 25 & 14 & 25 & 11 & 178 & 9,45 \\
\hline $\begin{array}{l}\text { Dikkat ve çok çalışma gerektiren bir ders } \\
\text { olarak muhasebe }\end{array}$ & 22 & 36 & 18 & 19 & 19 & 25 & 16 & 155 & 8,23 \\
\hline $\begin{array}{l}\text { Kurall1, düzenli ve sistematik bir ders } \\
\text { olarak muhasebe }\end{array}$ & 14 & 21 & 16 & 17 & 36 & 20 & 28 & 152 & 8,07 \\
\hline Zekâ gerektiren bir ders olarak muhasebe & 0 & 8 & 0 & 1 & 27 & 1 & 2 & 39 & 2,07 \\
\hline $\begin{array}{l}\text { Diğer bilim dallarıyla ilişkili bir ders } \\
\text { olarak muhasebe }\end{array}$ & 3 & 5 & 2 & 2 & 6 & 2 & 5 & 25 & 1,33 \\
\hline Parayla ilişkili bir ders olarak muhasebe & 2 & 0 & 2 & 0 & 2 & 0 & 6 & 12 & 0,64 \\
\hline Yol gösterici bir ders olarak muhasebe & 1 & 0 & 0 & 0 & 0 & 1 & 1 & 3 & 0,16 \\
\hline Toplam & 269 & 269 & 269 & 269 & 269 & 269 & 269 & 1883 & 100,00 \\
\hline
\end{tabular}

Tablo 12'de görüldüğg̈ gibi, genel muhasebe dersini alan öğrencilerin muhasebe algıları metaforları çoğunlukla "Zor, sıkıcı ve karmaşık bir ders olarak muhasebe" ( $N=975$, $\%=51,78)$, "Gerekli, faydalı ve önemli bir ders olarak muhasebe" $(\mathrm{N}=344, \%=18,27)$ ve "Heyecan verici bir ders olarak muhasebe" $(\mathrm{N}=178, \%=9,45)$ muhasebe algıları yer almaktadır. Öğrencilerin "Parayla ilişkili bir ders olarak muhasebe" $(\mathrm{N}=12, \%=0,64)$ ve "Yol gösterici bir ders olarak muhasebe" $(\mathrm{N}=3, \%=0,16)$ algıları ise diğer muhasebe algıları arasında daha azdir.

\section{BULGULAR İLE LITTERATÜRÜN KARŞILAȘTIRILMASI}

Muhasebe algılarının metafor kavramları yoluyla belirlendiği bu çalışmada, öğrencilerin yaygın olarak kullandıkları muhasebe metaforları sırasıyla "Siyah, yılan, acı biber, kış, saklambaç, kaktüs ve hesap makinesi" olduğu ve "Zor, sıkıcı ve karmaşık bir ders olarak muhasebe" ve "Gerekli, faydalı ve önemli bir ders olarak muhasebe" algıları ön plana çıkmıştır. Muhasebe algılarının belirlendiği bir çalışmada, "Siyah, kedi, brokoli, kış, saklambaç, kaktüs ve hesap makinesi" metafor kavramları ve "Zor, sıkıcı ve karmaşık bir ders olarak muhasebe" ve "Gerekli, faydalı ve önemli bir ders olarak muhasebe" algıları yaygın olarak kullanılmıştır (Erol Fidan, 2019: 30). Başka bir çalışmada ise, "Siyah, aslan (kaplan), sebze türü, kış, saklambaç, kaktüs ve hesap makinesi" muhasebe metaforları ve "Zor, sıkıcı ve karmaşık bir ders olarak muhasebe" ve "Gerekli, faydalı ve önemli bir ders olarak muhasebe" algıları ön plana çıkmıştır (Akpınar ve Yıldız, 2018: 91). Ayrıca muhasebe dersine karşı algıların; "Karmaşık bir sistem" (Güler vd., 2016: 308) ve "Gereksiz, sıkıcı ve angarya; isteksizlik ve amaçsızlık" (Ertuğrul ve Özdemir, 2014: 210) olduğu görülmüştür. Literatürde yapılan bu çalışma sonuçları araştırmayı destekler niteliktedir. Alanyazında yapılan çalışmalar ve bu araştırmanın bulguları dikkate alındığında, muhasebe dersinin genel olarak "Siyah, kış saklambaç, kaktüs ve hesap makinesi" metafor kavramları ile ilişsilendirildiği ve "Zor, sıkıcı 
ve karmaşık bir ders olarak muhasebe" algısının hakim olduğu anlaşılmaktadır. Bu olumsuz algının hakim olmasının nedenlerinin "sayısal ağırlıklı olması, ezbere dayalı olması, yeterli örnek çalışmaları yapılmaması, vaka çalışmaları yapılmaması, grup çalışmaları yapılmaması, görsel araçların kullanılmaması, öğretim elemanının yetersiz olması, ilgisizlik ve teori ve pratiğin farklı olması" (Dizman, 2015:169) olduğu düşünülmektedir. Diğer yandan muhasebe eğitiminde öğrenci beklentileri, öğretim yöntemleri ve teknoloji kullanımı faktörleri muhasebe algısında önemli olmakta (Apak vd., 2016: 186) ve bu faktörler öğrencilerin muhasebe algılarını etkilemektedir (Atmaca ve Çoşgun, 2014: 167).

Muhasebe dersinin tarih, politika, ekonomi, antropoloji ve psikoloji gibi disiplinler ile ilişskili olduğu (Hurt, 2007: 298), insan yaşamındaki sosyo-ekonomik problemlerin çözümünde muhasebeye ihtiyaç duyulduğu (Daştan, 2017: 1253) ve ayrıca muhasebenin üretim, pazarlama, halkla ilişkiler, insan kaynakları gibi alt sistemler ile doğrudan bağlantılı olduğu (Koçel, 2018: 75) düşünüldüğünde muhasebe dersinin ne denli "Gerekli, faydalı ve önemli ve diğer bilim dallarıyla iliş̧kili" olduğu görülecektir. Çalışmada ise "Gerekli, faydalı ve önemli bir ders olarak muhasebe" algısının "Diğer bilim dallarıyla ilişkili bir ders olarak muhasebe" algısına göre ön plana çıktığı sonucuna ulaşılmıştır. Bununla birlikte, işletme yöneticilerinin karar verme faaliyetlerinde muhasebe verilerine ihtiyaç duyması, işlemlerin para birimlerine göre yapılması ve hesap kodlarının belirli bir niteliğe ve işleyiş̧e sahip olması (Kaygusuz, 2012) muhasebe dersinin sırasıyla "Yol gösterici, parayla ilişkili ve kurallı, düzenli ve sistematik bir ders olarak muhasebe" olarak algılanmasına neden olmaktadır. Çalışmada ise öğrencilerin "Kurallı, düzenli ve sistematik bir ders olarak muhasebe" muhasebe algısı diğer iki muhasebe algılarına göre daha yaygın olduğu görülmüştür. Ayrıca, öğrenciler genel muhasebe dersini, diğer muhasebe algıları arasında, "Yol gösterici ve parayla ilişkili bir ders olarak muhasebe" algısı nadir görülmektedir.

\section{SONUÇ VE ÖNERILER}

Genel muhasebe dersini alan öğrencilerin muhasebe algılarının belirlendiği bu çalışmada öğrencilerin çoğunlukla; 18-21 yaş aralığında ve erkek öğrenciler olduğu, Sağllk Kurumları İşletmeciliği Programı'na kayıtlı olduğu ve dersi geçtiği görülmüştür. Öğrencilerin muhasebe kavramına iliş̧in metaforları arasında sırasıyla "Siyah, yılan, acı biber, kış, saklambaç, kaktüs ve hesap makinesi" ön plana çıktığ 1 ve ayrıca öğrencilerin muhasebe algıları arasında "Zor, sıkıcı ve karmaşık bir ders olarak muhasebe" ve "Gerekli, faydalı ve önemli bir ders olarak muhasebe" algılarının yaygın olduğu sonuçlarına ulaşılmıştır. Çalışmada elde edilen sonuçlar dikkate alınarak şu öneriler geliştirilmiştir:

- "Zor, sıkıcı ve karmaşık bir ders olarak muhasebe" olumsuz muhasebe algısının giderilmesine çözüm önerisi olarak muhasebe dersinin "Gerekli, faydalı, önemli ve diğer bilim dallarıyla ilişkili bir ders" özelliklerine de sahip olduğunun vurgulanmasının ve bu algının nedenlerine yönelik araştırmalar yapılmasının,

Genel muhasebe dersinin planlanmasında dijital platformlarının (Google Classroom, Kahoot, EdPuzzle, EdModo vb.), drama etkinliklerinin, sektörlerde kullanılan muhasebe programlarının, vaka çalışmalarının ve ödev, proje ve vaka çalışmalarına dayalı notlandırma sistemlerinin kullanılmasının; öğretim metotlarının yenilenmesinin; aktif öğrenci katılımının sağlanmasının ve öğrenci motivasyonunu arttırıcı ortamın oluşturulmasının, 
- Genel muhasebe dersini alan ön lisans ve lisans öğrencilerinin algisal farkl11ıkların bölümlere/programlara göre belirlenmesinin,

- $\quad$ Türkiye'de genel muhasebe dersini alan öğrencilerin ortak muhasebe algılarının belirlenmesinin ve gerekli çözümlerin geliştirilmesinin,

- Genel muhasebe dersi ile birlikte diğer muhasebe derslerini (Maliyet Muhasebesi, Finansal Muhasebe vb.) de dikkate alarak muhasebe algilarındaki farkl11kkları belirlemeye yönelik çalışmalar yapılmasının yararlı olacağı düşünülmektedir.

\section{KAYNAKLAR}

Abay, Şükriye Ece- Sezer, Barış- Nezaket Bilge (2017), "Hekim Adaylarının Hekim Kimliğine İlişkin Algıları: Hacettepe Üniversitesi Tıp Fakültesi Metafor Analizi Örneğì, Sürekli Tıp Eğitimi Dergisi, Cilt 26, Sayı 1, ss. 1-8.

Akpınar, Sema- Yıldız, Şule (2018), "Muhasebe Eğitimi Alan Öğrencilerin Muhasebe Algılarına Yönelik Metaforlar”, Muhasebe Finansman Dergisi, Sayı 77, ss. 91-114.

Altun, Taner- Camadan, Fatih (2013), "Rehber Öğretmenlerin Rehber Öğretmen (Psikolojik Danışman) Kavramına İlişkin Algıılarının Metafor Analizi Yoluyla İncelenmesi”, Kastamonu Eğitim Dergisi, Cilt 21, Sayı 3, ss. 883-918.

Apak, İbrahim- Duman, Haluk- Özpeynirci, Rabia- Karakışla, Enver (2016), “Türkiye'de Muhasebe Eğitimi: Türkiye Muhasebe Eğitimi Sempozyumu Örneği”, International Journal Of Human Sciences, Cilt 13, Say1 1, ss. 169-196.

Atmaca, Metin- Çoşgun, Nurcan (2014), “Çanakkale Onsekiz Mart Üniversitesi'ne Bağlı Meslek Yüksekokullarında Muhasebe Eğitimi Alan Öğrencilerin Motivasyonlarının ve Beklentilerinin Değerlendirilmesine Yönelik Bir Araştırma", Çankırı Karatekin Üniversitesi İ̈BF Dergisi, Cilt 4, Sayı 1, ss. 167-184.

Aydın, Emre- Sulak, Süleyman Erkam (2015), "Sınıf Öğretmeni Adaylarının Değer Kavramına Yönelik Metaforik Algıları”, Bartın Üniversitesi Eğitim Fakültesi Dergisi, Cilt 4, Say1 2, ss. 482-500.

Aygün, Davut- Gerekan, Bilal (2012), "Muhasebe Dersini İlk Defa Alan Öğrencilerin Derse Yönelik Algılarının Tespiti: Karşılaştırmalı Bir Alan Araştırması", Yönetim ve Ekonomi Araştırmaları Dergisi, Sayı 18, ss. 48-62.

Başkale, Hatice (2016), "Nitel Araştırmalarda Geçerlik, Güvenirlik ve Örneklem Büyüklüğünün Belirlenmesi”, Dokuz Eylül Üniversitesi Hemşirelik Fakültesi Elektronik Dergisi, Cilt 9, Say1 1, ss. 23-28.

Beyoğlu, Aylin- Ergin, Demirali Yaşar (2019), "Öğretmen Adaylarının Şiddet Kavramına İlişkin Algılarının Metafor Analizi Yoluyla İncelenmesi”, Trakya Üniversitesi Sosyal Bilimler Dergisi, Cilt 21, Sayı 1, ss. 283-294.

Büyükalan, Sevil- Yaylac1, Zeynep (2018), "Normal Gelişim Gösteren Öğrenciler İle Kaynaştırma Öğrencilerinin Sosyal Bilgiler Kavramına İlişkin Metafor Algıları", 
Ankara Üniversitesi Eğitim Bilimleri Fakültesi Özel Eğitim Dergisi, Cilt 19, Say1 4, ss. 679-697.

Chen, Bryan H- Hsu, Ming-Shan- Chen, Mei-Hua (2013), "The Relationship Between Learning Attitude and Anxiety in Accounting Classes: The Case of Hospitality Management University Students in Taiwan", Qual Quant, Number 47, pp. 28152827.

Cheng, Kai-Wen (2007), "The Curriculum Design in Universities from The Perspective of Providers in Accounting Education", Education, Volume 127, Number 4, pp. 581-590.

Çalışkan, Nihal (2013), "Kavramsal Anahtar Modeli İle Metafor Ve Deyim Öğretimi”, Bilig, Say1 64, ss. 95-122.

Çelenk, Hakan- Atmaca, Metin- Horasan, Emre (2010), “Marmara Üniversitesinde Muhasebe Eğitimi Alan Öğrencilerin Muhasebe Alanına Bakış Açıların Değerlendirilmesine Yönelik Bir Araştırma”, Öneri Dergisi, Cilt 9, Sayı 33, ss. 159-171.

Çelik, Tülay- Sağlam Arı, Güler (2017), "Bankalarda Örgüt Kültürünün Belirlenmesinde Alternatif Bir Yöntem Olarak Metafor Analizi”, Eskişehir Osmangazi Üniversitesi İIBF Dergisi, Cilt 12, Say1 1, ss. 31-64.

Daştan, Abdulkerim (2017), "Muhasebenin Toplumsal Gelişimine Katkısı: Türkiye'nin Muhasebe Bilgisi İhtiyacı, Atatürk Üniversitesi İktisadi ve İdari Bilimler Dergisi”, Cilt 31, Say1 5, ss.1253-1275.

Demirel Utku, Burcu- Erol, İbrahim (2015), "Lisans Öğrencilerinin Muhasebeye Giriş Dersine Yönelik Algılamalarının Belirlenmesi”, Journal of Accounting, Finance and Auditing Studies, Cilt 1, Say1 3, ss. 91-104.

Dizman, Şakir (2015), “İktisadi ve İdari Bilimler Fakültesinde Öğrencilerin Muhasebe Dersinde Başarısızlık Nedenleri ve Çözüm Önerileri”, Sosyal Bilimler Dergisi, Cilt 1, Say1 1, ss. 158-174.

Doğan, Hulusi- Üngören, Engin (2010), "İşletmelerde Metafor Kavramı Ve Önemi: Yöneticilerin Stratejik İletişim Ve Paylaşım Araçları Olarak Metaforlar Ve Etkin Kullanım Yolları", Alanya İşletme Fakültesi Dergisi, Cilt 2, Sayı 2, ss. 63-76.

Duman, Haluk- Apak, İbrahim- Yücenurşen, Mehmet- Peker, Ali Aykut (2015), "Determing The Anxieties of Accounting Education Students: A Sample of Aksaray University", Social and Behavioral Sciences, Number 174, pp. 1834-1840.

Erol Fidan, Meral (2019), "Lisans Öğrencilerinin Muhasebe Eğitimi Hakkındaki Metaforik Algıları: Bilecik Şeyh Edebali Üniversitesi Örneği”, Uluslararası Muhasebe ve Finans Araştırmaları Dergisi, Cilt 1, No 1, ss. 30-57.

Erol, İbrahim- Demirel Utku, Burcu (2015), "Finansal Muhasebe Derslerinde Öğrencilerde Oluşan Kavram Yanılgılarının İncelenmesi”, International Journal of Social Sciences and Education Research, Cilt 1, Say1 4, ss. 1307-1319. 
Ertuğrul, İrfan- Özdemir, Serkan (2014), "Muhasebe Dersini Alan Ön Lisans ve Lisans Öğrencilerinin Derse Yönelik Tutumlarının Tespiti: Ege Bölgesinde Bir Uygulama”, Niğde Üniversitesi İiBF Dergisi, Cilt 7, Sayı 1, ss. 204-214.

Fidan, Tuncer (2017), “Örümcek Ağı Olarak Örgütler: Örgütsel Ağlara İlişkin Metaforik Bir Değerlendirme", Ahi Evran Üniversitesi Sosyal Bilimler Enstitüsü Dergisi, Cilt 3, Say1 2, ss. 169-185.

Franco, Alexander- Roach, Scott S (2017), "Factors That Determine Accounting Anxiety Among Users of English as a Second Language within an International MBA Program", International Journal of Learning, Teaching and Educational Research, Volume 16, Number 1, pp. 22-37.

Güler, Mursel- Agca, Ahmet- Boz, Dursun (2016), "İşletme Öğrencilerinin Muhasebe Algilarının Metaforlar Yardımıyla Anlatılması", Global Business Research Congress, pp. 298-309.

Hurt, Bob (2007), "Teaching What Matters: A New Conception of Accounting Education", Journal of Education for Business, Volume 82, Number 5, pp. 295-299.

İbret, B. Ünal- Recepoğlu, Ergün- Karasu Avc1, Emine- Recepoğlu, Serpil (2018), “Öğretmen Adaylarının Demokrasi Kavramına Yönelik Metafor Algıları", Journal of History Culture and Art Research, Cilt 7, Say1 5, ss. 421-441.

Jensen, Devon (2006), "Metaphors As A Bridge To Understanding Educational And Social Contexts", International Journal of Qualitative Methods, Volume 5, Number 1, pp. 3654.

Jones, Jefferson P- Fields, Kent T (2001), "The Role of Supplemental Instruction in The Firt Accounting Course", Issues in Accounting Education, Volume 16, Number 4, pp. 531547.

Kalayc1, Serpil (2018), "İlkokul Öğrencilerinin Bilim Ve Fen Bilimleri Dersi Kavramlarına Yönelik Algılarının Metafor Yoluyla Belirlenmesi”, Uluslararası Sosyal ve Eğitim Bilimleri Dergisi, Cilt 5, Say1 9, ss. 1-21.

Kale, Emine- Çiçek, Ülkü (2015), "Hemşirelerin Kendi Mesleklerine İlişkin Metafor Algıları, Sağlık ve Hemşirelik Yönetim Dergisi”, Cilt 3, Sayı 2, ss. 142-151.

Kandemir, Tuğrul- Kardeş, Zafer- Baykut, Ender (2016), "Meslek Yüksekokulu Öğrencilerinin Muhasebe Eğitimine Bakış Açıları: Afyon Kocatepe Üniversitesi Meslek Yüksekokulları Örneği”, Afyon Kocatepe Üniversitesi Sosyal Bilimler Dergisi, Cilt 18, Say1 2, ss. 133-151.

Karaçam, Sedat- Aydın, Fatih (2014), “Ortaokul Öğrencilerinin Teknoloji Kavramına İlişkin Algılarının Metafor Analizi”, Gaziantep University Journal of Social Sciences, Cilt 13, Say1 2, ss. 545-572. 
Karakuş, Ufuk (2013), "Depremi Yaşamış Ve Yaşamamış Öğrencilerin Deprem Algıılarının Metafor Analizi İle İncelenmesi”, Doğu Coğrafya Dergisi, Cilt 18, Say1 29, ss. 97-116.

Karavadar, Alper- Paça, Muammer (2019), "Muhasebe Dersine İlişkin Alg1 ve Kaygı: Giresun Üniversitesi İşletme Bölümü Öğrencileri Üzerine Bir İnceleme", Gümüşhane Üniversitesi Sosyal Bilimler Enstitüsü Elektronik Dergisi, Cilt 10, Say1 1, ss. 73-83.

Kaya, Mehmet Fatih (2013), "Sosyal Bilgiler Öğretmen Adaylarının Küresel Isınma Kavramına Yönelik Metafor Algıları”, Doğu Coğrafya Dergisi, Cilt 18, Sayı 29, ss. $117-134$.

Kaygusuz, Sait Y (2012), İşletmenin Dili: Muhasebe ve Hesap, İçinde Genel Muhasebe I, Banar, Kerim- Ekergil, Vedat (Ed.), Açıköğretim Fakültesi Yayını No: 1620, Eskişehir, .ss. 8/10/49.

Ke, Yannan- Zhang, Yan- Jiang, Jiang- Xu, Yan (2019), "It's Hip to be Square: Grounding Moral Traits in Geometric Shapes", International Journal of Psychology, Number 2, pp. 1-9.

Koçel, Tamer (2018), İşletme Yöneticiliği, Genişletilmiş 17. Baskı, Beta Basın Yayım, İstanbul.

Köroğlu, Özlem- Ulusoy Yıldırım, Hasret- Avcıkurt, Cevdet (2018), "Kültürel Miras Kavramına İlişkin Algıların Metafor Analizi Yoluyla İncelenmesi”, Turizm Akademik Dergisi, Cilt 5, Say1 1, ss. 98-113.

Kutlu, Hüseyin Ali- Öztürk, Seyhan- Yılmaz, Tuncer- Gerekan, Bekir (2017), "Muhasebe Eğitiminde Ölçme ve Değerlendirme: Öğrencilerin Bakışı Üzerine Bir Araştırma", Muhasebe ve Finansman Dergisi, Say1 74, ss. 15-36.

Martinis, Karen- Tidd, Ronald (2011), "Does Performing Additional Work Improve A Student's Accounting Principle Grade? First Analysis", ASBBS Annual Conferans, Las Vegas, pp. 432-434.

Nas, Eşref- Sak, Ramazan (2018), “Okul Psikolojik Danışmanlarının Velilere İlişkin Algıları: Bir Metafor Çalışması”, Gaziantep Üniversitesi Eğitim Bilimleri Dergisi, Cilt 2, Sayı 1 , ss. 59-75.

Okur Özdemir, Ayşe- Arık, Recep Serkan (2018), "Methodological and Contextual Investigation of Metaphor Analysis Studies in the Field of Educational Administration, Kastamonu Education Journal", Volume 26, Number 3, pp. 965-974.

Onay, Meltem- Ergüden, Sevinç (2012), "Yeni Bir Metafor: Kurum DNA’sı, Sosyal ve Beşeri Bilimler Dergisi”, Cilt 4, Sayı 1, ss. 203-212.

Özbek, C Yiğit (2015), "Farklı Eğitim Programlarındaki Öğrencilerin Genel Muhasebe Dersine İlişkin Algıları”, Eğitim ve Öğretim Araştırmaları Dergisi, Cilt 4, Sayı 2, ss. 24-34. 
Öztaş, Dilek- Erdem, Özgür- Kurt, Burak- Akbaba, Muhsin (2018), "Hekim Adaylarının AIDS Kavramına İlişkin Algıları: Metafor Analizi Örneği Ve Bilişsel Yapıları Bağımsız Kelime İlişkilendirme Test Örneği”, Türkiye Sağlık Bilimleri ve Araştırmaları Dergisi, Cilt 1, Sayı 1, ss. 24-35.

Pesen, Ata- Kara, İdris- Gedik, Mehmet (2015), "Çocuk Gelişimi Bölümü 2. Sınıf Öğrencilerinin Müdür Kavramına İlişkin Metafor Algıları”, Siirt Üniversitesi Sosyal Bilimler Enstitüsü Dergisi, Say1 5, ss. 28-48.

Saban, Ahmet (2009), "Öğretmen Adaylarıın Öğrenci Kavramına İlişskin Sahip Oldukları Zihinsel İmgeler", Türk Eğitim Bilimleri Dergisi, Cilt 7, Sayı 2, ss. 281-326.

Sağlam Kaya, Yasemin (2017), “Öğretmen Adaylarının Matematiksel Örnekleri Algılayışları Üzerine Bir Metafor Analizi”, Bartın Üniversitesi Eğitim Bilimleri Fakültesi Dergisi, Cilt 6, Say1 1, ss. 48-67.

Süer, Sedef- Sezgin, Kasım- Oral, Behçet (2017), "Z Kuşağındaki Öğrencilerin İnternete İlişkin Algılarının Belirlenmesi: Bir Metafor Çalışması”, Elektronik Eğitim Bilimleri Dergisi, Cilt 6, Say1 12, ss. 190-203.

Taşdemir, Mehmet- Taşdemir, Figen (2016), "Öğretmen Adaylarının Bilimsel Araştırma Kavramına Yükledikleri Metaforlar”, Ahi Evran Üniversitesi Kırşehir Eğitim Fakültesi Dergisi, Cilt 17, Say1 1, ss. 419-438.

Uğurlu, Zeynep (2018), “Öğretmen Adaylarının Üniversite Kavramına İlişkin Algılarının Metafor Analizi”, Çağdaş Yönetim Bilimleri Dergisi, Cilt 5, Sayı 1, ss. 82-97.

Uyar Suiçmez, Tuğba (2019), “ Psikoterapide Metafor Kullanımı ve Değişen Anlamı: Depresif Bir Olgu Sunumu”, Ayna Klinik Psikolojisi Dergisi, Cilt 6, Say1 1, ss. 85101.

Uygun, Tuğba- Göktürk, Burçin- Usta, Neslihan (2016), "Üniversite Öğrencilerinin Matematik Problemine İlişkin Algılarının Metafor Yoluyla Analiz Edilmesi”, Bartın Üniversitesi Eğitim Fakültesi Dergisi, Cilt 5, Sayı 2, ss. 536-556.

Üzüm, Burcu- Uçkun, Seher (2019), "Post Modern Bir Metafor: Kuantum Organizasyonlar Ve Kuantum Liderlik", The Journal of Social Science, Cilt 3, Say1 5, ss. 80-90.

Varıcı, İdris- Bulut, Elif (2015), "Muhasebe Dersine Yönelik Endişeler ve Tutumlar: Samsun Ondokuz Mayıs Üniversitesi İktisadi ve İdari Bilimler Fakültesi Örneği”, Atatürk Üniversitesi Sosyal Bilimler Enstitüsü Dergisi, Cilt 19, Say1 3, ss. 293-314.

Warwick, Jon- Howard, Anna (2016), "Mathematical Anxiety as an Inhibitor of Skills Development in Accounting Students", Mathitudes, Volume 1, Number 1, pp. 1-15.

Yıldırım, Ali- Şimşek, Hasan (2013), Sosyal Bilimlerde Nitel Araştırma Yöntemleri, 9. Genişletilmiş Baskı, Seçkin Yayıncılık, Ankara. 
Yıldırım, Suat (2015), “Genel Muhasebe Dersi Alan Öğrencilerin Derse İlişskin Beklentileri ve Başarı Durumlarının Değerlendirilmesi”, Muhasebe ve Denetime Bakış Dergisi, Cilt 14, Say1 44, ss. 1.

Zembat, Rengin- Tunçeli, Halil İlknur- Akşin, Ezgi (2015), “Okul Öncesi Öğretmen Adaylarının Okul Yöneticisi Kavramına İlişkin Algılarına Yönelik Metafor Çalışması", Hacettepe University Faculty of Health Sciences Journal, No 2, ss. 446459. 